\title{
Follicle development and selection: past, present and future
}

\author{
R. Webb ${ }^{1,5}$, J. Buratini ${ }^{2}$, J.H. Hernandez-Medrano ${ }^{3}$, C.G. Gutierrez ${ }^{3}$, B.K. Campbell ${ }^{4}$ \\ ${ }^{1}$ Division of Animal Sciences, School of Biosciences, University of Nottingham, Nottinghamshire, UK. \\ ${ }^{2}$ Department of Physiology, Institute of Biosciences, Sao Paulo State University, Botucatu, São Paulo State, Brazil. \\ ${ }^{3}$ Department of Reproduction, Faculty of Veterinary Medicine, National Autonomous University of Mexico, \\ Mexico City, Mexico. \\ ${ }^{4}$ Department of Obstetrics and Gynaecology, Division of Clinical Sciences, University of Nottingham, \\ Queen's Medical Centre, Nottingham, UK.
}

\begin{abstract}
This paper reviews progress that has been made over the last 50 years and discusses how the development and application of new technologies have been utilized to increase our understanding of the development and selection of the dominant follicle. Our increased knowledge from research carried out worldwide, has demonstrated that the development of the dominant follicle, and importantly the production of a good quality oocyte, are controlled by a set of complex and interactive extra- and intra-ovarian control systems, impacted by underlying genetic and external environmental factors, such as nutrition. In totality this has resulted in improvements in fertility, as demonstrated by the impact of diet on oocyte quality and increased pregnancy rates. However, given the increasing global challenges of food security, coupled with climate change, more in-depth understanding of these complex multifactorial control systems will have even greater significance in overcoming today's livestock production challenges, including some that were present over 50 years ago. In conclusion, the continuing development of new technologies, coupled with new knowledge and understanding of these complex control systems, should ensure that ruminant fertility is maximized, while ensuring good animal welfare within sustainable production systems.
\end{abstract}

Keywords: cattle, follicle, ovary, reproduction.

\section{Introduction}

Understanding the mechanisms regulating ovarian follicle development is central to the diagnosis and treatment of infertility. Cyclical variation in the number and size of ovarian follicles in cattle was being studied in detail over 90 years ago (Hammond, 1927; Rajakoski, 1960; Bane and Rajakoski, 1961). Indeed these studies confirmed the presence of large follicles throughout the greater part of the estrous cycle. This hypothesis of phasic follicular development was also supported by the work of others around that time and more recently (Cupps et al., 1959; Asdell, 1960, Ireland et al., 1979). In a review published over 5 years ago (Scaramuzzi et.al., 2011), which provided an update on a previous review published nearly 20 years ago (Scaramuzzi et al., 1993) discussing factors that regulate folliculogenesis and ovulation rate in ruminants, there was a dedication to the work of Hannah Peters carried out in the 1960s and 1970s. This work was presented at an ovarian workshop in Glasgow, UK, over 40 years ago. Peters and her colleagues (Peters et al., 1975), in studies of ovarian function in rodents and humans, together with information from other scientists published during the previous 40 years, confirmed these earlier ruminant studies. Importantly Peters et al. went on to conclude that: (1) the initiation of follicular growth is continuous; (2) follicles grow sequentially and continue to grow until they die or ovulate; (3) the number of follicles that start to grow is dependent upon the size of the small follicle pool; (4) the initiation of follicular growth is independent of gonadotropins and involves intra-ovarian factors; (5) the continued growth of medium and large follicles become increasingly dependent upon gonadotropins and (6) exogenous gonadotropins reduce the incidence of atresia in large follicles.

Since this earlier work over 50 years ago, there have been major technological developments that have provided the tools to elucidate in more detail the patterns and control of follicular growth and confirm whether similar mechanisms are operating in ruminants, as well as in rodents and humans. For example, these technological developments have included more specific and sensitive hormone assays for gonadotropins (Niswender et al., 1969; Staigmiller et al., 1979), steroids (Webb et al., 1985) and metabolic hormones (Gutierrez et al., 1997a); ovarian ultrasound scanning and ovum pick-up (Pierson and Ginther, 1984; Pieterse et al., 1988); physiological models for investigating hormone feedback mechanisms (Hauger et al., 1977; Martin et al., 1988; Price and Webb, 1988; Campbell et al., 1995; Gong et al., 1995); gonadotropin receptor binding studies (Webb and England, 1982a, b; Ireland and Roche, 1983); more physiologically relevant in vitro culture methods for follicular cells (theca (Campbell et al., 1998), granulosa (Campbell et al., 1996; Gutierrez et al., 1997b), oocytes (Fouladi-Nashta et al., 2005)), preantral follicles (Gutierrez et al., 2000); molecular biological techniques (Bao et al., 1997; Armstrong et al., 1998; Bao and Garverick, 1998; Garverick et al., 2002) and ovarian tissue transplant studies (Gosden et al., 1994; Baird et al., 1999, Campbell et al., 2014).

The integration of this panoply of approaches

${ }^{5}$ Corresponding author: bob.webb@nottingham.ac.uk

Phone: +44(115)951-6051

Received: May 25, 2016

Accepted: July 28, 2016 
has been crucial in increasing our understanding of the key mechanisms involved in the selection and development of the dominant follicle in ruminants, confirming some of the similar overarching mechanisms as concluded by Peters et al., (1975) for rodents and humans. As will be discussed, studies carried out worldwide have demonstrated the complexity of the overall process, the redundancy of various control systems within the overall process and how these processes can be impacted by the interaction of extraand intra-ovarian mechanisms, as well as environmental factors such as nutrition.

\section{Follicle development}

Folliculogenesis is a lengthy and intricately regulated process, including the dramatic proliferation and precisely controlled differentiation of both the somatic and germ cells (Webb and Campbell, 2007). Much of the earlier work focused on the mechanisms controlling antral follicle development because of the strategic and commercial importance of anovulatory infertility and controlled ovarian stimulation. However, more recently interest in early follicle development has increased because factors, such as nutrition, have been shown to have an impact throughout follicle development, including on oocyte quality. Furthermore, primordial and preantral follicles represent a significant store of oocytes, particularly from animals of high genetic merit, that could be developed to overcome the fact that $99.9 \%$ of these oocytes are lost to atresia.

\section{Early follicle development}

Primordial follicles represent the source from which follicles will be recruited for growth throughout reproductive life, with individuals containing around 100,000 to 250,000 at birth (Turnbull et al., 1977). Twenty years of work mainly in sheep, but also cattle and pigs, initially transplanting ovarian cortex tissue (Gosden et al., 1994), and subsequently whole ovaries (Campbell et al., 2014), to the ovarian pedicle, demonstrated that the tissue does develop a blood supply with subsequent follicle growth and pregnancies. These experiments confirmed the earlier histological experiments that primordial follicles take 3 to 5 months to reach the dominant follicle stage, with much of this time spent in the preantral stages of development.

These experiments provided some of the first evidence that gonadotropins can affect the rate of development of preantral follicles in vivo, but also suggested the existence of a gonadotropin-independent intraovarian feedback loop regulating both the rate of primordial follicle initiation and primary and secondary follicle development. Indeed, a large body of work from groups around the world demonstrated that preantral follicles, as well as acquiring steroid enzymes and gonadotropin receptors, acquire a panoply of local growth factors, including members of the insulin-like growth factor (IGF) family and transforming growth factor- $\beta$ (TGF- $\beta$ ) super family (Campbell et al., 2003b, 2014; Webb et al., 2003; McNatty et al., 2007; Webb and Campbell, 2007). Furthermore in vitro culture studies demonstrated that bovine preantral follicles are responsive to these factors (Gutierrez et al., 2000)

\section{Antral follicle development and maturation}

Earlier work in sheep and cattle investigated the patterns of steroidogenesis during antral follicle growth. They demonstrated that testosterone and estradiol are elevated when peripheral preovulatory LH concentrations are rising (England et al., 1981). However, there was a significant increase in testosterone in both small and large antral follicles, whereas estradiol increased only in large follicles. Work in mono-ovulatory species, such as cattle, demonstrated that the largest (dominant) follicle is responsible for approximately $90 \%$ of the estradiol secreted at estrus (Staigmiller et al., 1982). It was also confirmed at this time that the number of thecal and granulosa cell $\mathrm{LH}$ receptors in ovulatory follicles was significantly correlated with both follicular fluid estradiol concentrations and with in vitro estradiol production. Importantly, the presence of LH receptors, particularly in granulosa cells, was demonstrated to be an excellent marker for the identification of the ovulatory follicle (Staigmiller et al., 1982; Webb and England, 1982a, b). Also that the increased number of thecal and granulosa cell LH receptors identified during the preovulatory period, is part of the final maturational process that ensures that ovulation will occur in response to the preovulatory LH surge. Subsequent work, including molecular biological studies up to the present day, have confirmed these findings and demonstrated the importance of local components of both the TGF- $\beta$ and IGF systems that affect the maturation of the ovulatory follicle and functional competency of the subsequent corpus luteum (CL; Gregson et al., 2016).

The use of ovarian ultrasound scanning throughout the estrous cycle in cattle confirmed the wave-like pattern in ovarian follicle development, as small antral follicles progress from a gonadotropinresponsive to gonadotropin-dependent stages of development (Pierson and Ginther, 1984; Ginther et al., 2003). The use of this technology also aided the further clarification of the different stages of follicular development: (i) early gonadotropin-independent (primordial to early preantral), (ii) gonadotropinresponsive (preantral to small antral) and (iii) gonadotropin-dependent (antral to large antral) stages of follicle development in monovular species. The progression of antral follicles through these stages of development requires $\mathrm{FSH}$ concentrations to reach a critical threshold level in the peripheral circulation for the synchronous recruitment of a cohort of gonadotropin-responsive small antral follicles (see Ginther et al., 1996; Adams, 1999; Webb et al. 1999, 2003; Webb and Campbell, 2007). In one of the first comprehensive studies investigating the action of inhibin, it was concluded that there are basic differences in the way that ovarian feedback acts to control the secretion of LH and FSH in the ewe (Martin et al., 1988). Follicle stimulating hormone secretion was 
shown to be primarily controlled by the synergistic action of estradiol and inhibin on the anterior pituitary gland (Baird et al., 1991), while the secretion of LH is inhibited during the follicular phase by the effect of estrogen at the level of the hypothalamus and pituitary gland and during the luteal phase by the synergistic action of estradiol and progesterone at the hypothalamic level.

Additional work in cattle, using laparoscopy, demonstrated that these large luteal-phase follicles, as well as follicles around the time of luteolysis, are also capable of ovulating in response to human chorionic gonadotropin (hCG; Price and Webb, 1989). While these less mature follicles can ovulate during the midluteal phase, progesterone production by these induced CL is attenuated (see Webb et al., 1992; Gregson et al., 2016). Gonadotropin-dependent follicles require a constant supply of FSH to continue their development, including the expression of $\mathrm{P} 450$ side chain cleavage (P450scc) and $\mathrm{P} 450$ aromatase (P450arom) in granulosa cells, together with steroid 17 alpha-hydroxylase (P450c17) in theca cells, which increases the production of estradiol within the granulosa cells of the follicle (Webb et al., 1999; Garverick et al., 2002). When bovine follicles reach 7 to $9 \mathrm{~mm}$ in diameter, one or two of this group are selected to continue growing and become either the dominant or subordinate follicle (Webb et al., 1999; Ginther et al., 2003; Mihm and Evans, 2008). It has been demonstrated that the future dominant follicle acquires the ability to growth under low FSH conditions by transferring its gonadotropin dependency from FSH to LH (see Fig. 1; Campbell et al., 2003b). Furthermore, the decrease in FSH concentration suppresses the emergence of a new follicular wave (Campbell et al., 1995). Numerous studies in both sheep and cattle have shown that a window, requiring appropriate LH concentrations, exists to enable normal pre-ovulatory follicle development (Beg et al., 2001; Garverick et al., 2002; Scaramuzzi et al., 2011).
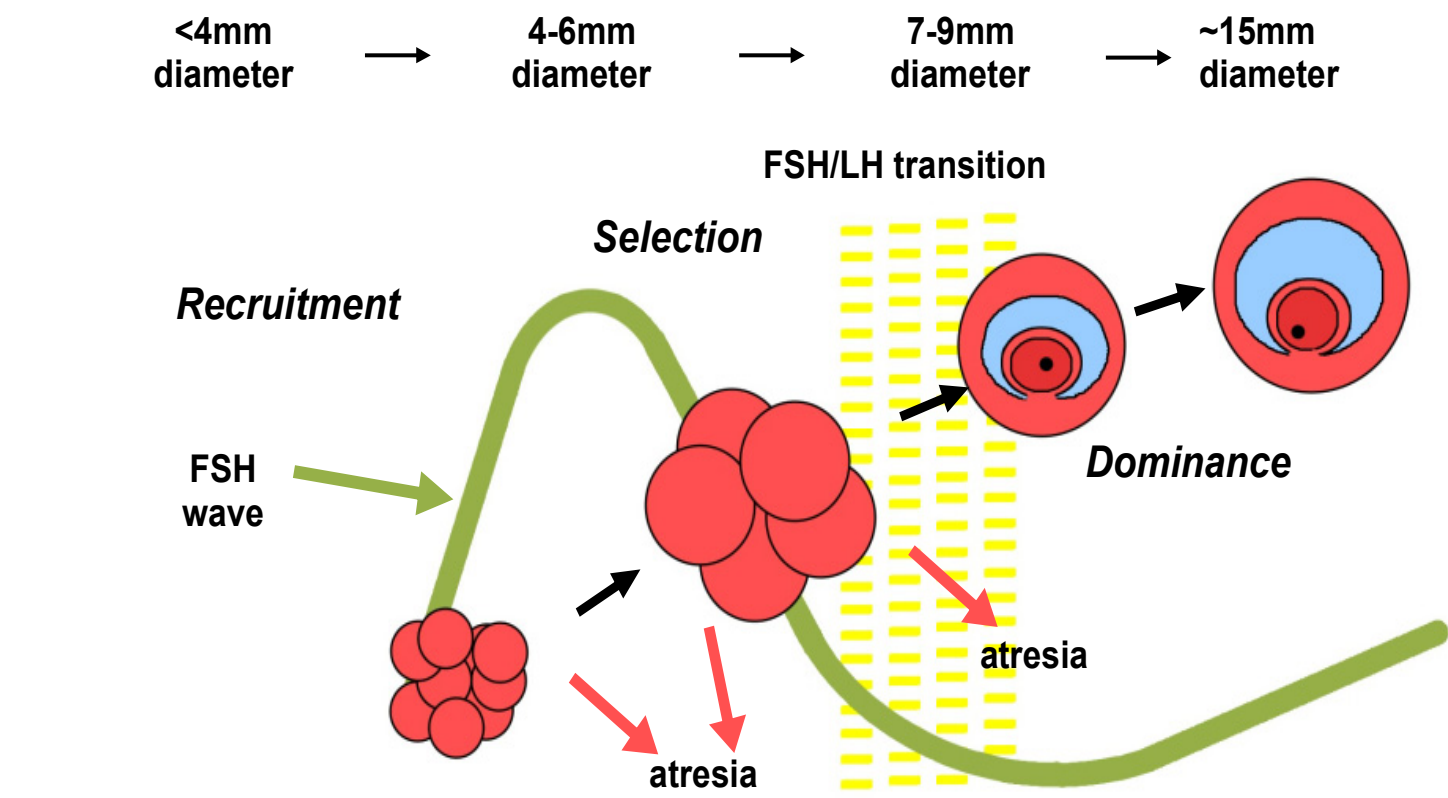

\section{Gonadotropin} influenced $\longrightarrow$ FSH dependent

\section{LH dependent}

Figure 1. The role of gonadotropins in follicular selection and dominance in cattle. Note the transition period when follicles become LH dependent. Adapted from Webb and Campbell (2007).

\section{Control and manipulation of ovulation rate}

Initial work in sheep indicated that follicular dominance appears to be less pronounced in ewes, in comparison to mono-ovulatory species such as cattle (Driancourt et al., 1991). Hence species such as sheep could be more amenable to manipulating ovulation rate for production purposes (see Webb et al., 1999). Indeed treatment with either a variety of steroid antisera or a $3 \beta$-hydroxysteroid dehydrogenase inhibitor increased ovulation rate (Land et al., 1983; Webb, 1987). These studies demonstrated that the mechanisms controlling ovulation rate, as distinct from those controlling the occurrence of ovulation, are operative in both the breeding season and seasonal anestrus. Similar experiments in cattle demonstrated that active immunization against a testosterone conjugate resulted in variable responses including anestrus and a high incidence of follicular cysts. However, those heifers that resumed spontaneous estrous activity did so with an increased incidence of multiple ovulations (Price et al., 1987).

Mechanisms controlling follicular recruitment into the population of gonadotropin-dependent follicles are different from the mechanisms controlling the selection of the follicles destined to ovulate (Webb et al., 1989). A significant amount of work worldwide, in a variety of breeds of sheep with differing ovulation 
rates, showed no qualitative or quantitative differences in the pattern of secretion of either pituitary gonadotropins or ovarian hormones (Souza et al., 1997). It was postulated that in breeds that carried the major $\mathrm{FecB}$ gene, which confers a significant increase in ovulation rate, the major site of action is at the level of ovary. Indeed a number of other significant studies were published by several groups at the turn of the century confirming the single gene effect on ovulation rate was operating at the level of the follicle (see Hanrahan, 2003). This conclusion was confirmed in a subsequent physiological study (Campbell et al., 2003a) where despite suppressing endogenous gonadotropins and subsequently stimulating ovulatory follicle development with exactly the same pattern and level of exogenous gonadotropins, FecB gene carriers continued to display the characteristic increase in the number of ovulatory follicles that mature and ovulate at smaller diameters, when compared with non-gene carriers. These results provided additional evidence that the $\mathrm{FecB}$ mutation acts at the level of the ovary by increasing the sensitivity of follicular cells to gonadotropic stimulation.

In a more recent study, a series of six experiments (Gong et al., 2016; Roslin Institute (Edinburgh), Midlothian, UK; University of Nottingham, UK unpublished observations) were carried out in cattle to define the physiological concentrations of FSH and LH required for the selection of the dominant follicle. The main conclusions from this study were (1) physiological concentrations of FSH given as a continuous infusion and for an adequate duration, in the presence of basal $\mathrm{LH}$, are capable of inducing a multiple ovulatory response; (2) initial exposure to FSH followed by $\mathrm{LH}$ pulses alone can stimulate the development of multiple preovulatory follicles; (3) LH pulses appear not to have a major effect on the pattern of preovulatory follicle development, although adequate LH pulsatile support is required for full estradiol synthesis and the acquisition of ovulatory competence of preovulatory follicles and (4) that the duration of initial exposure to FSH and the ability to transfer the dependence from FSH to LH are critical for the selection of a single dominant follicle.

Overall these studies confirmed that it is more challenging to have controlled increases in ovulation rate in cattle, where there is a greater drive for the development of a single dominant ovulatory follicle, in comparison with sheep. The various patterns of follicular growth and maturation seen in the different breeds of sheep is due to the presence of a number of pathways through which higher ovulation rate can both be achieved, but also manipulated. Possible pathways of ovulation rate control are described in the review of Scaramuzzi et al. (2011).

These gonadotropin infusion studies in cattle also demonstrate that with a physiological pattern of gonadotropins, a single ovulation with a functional CL can be achieved. Taken together, the decades of previous work have resulted in a more detailed understanding of mechanisms controlling the development of the dominant follicle for improving
MOET protocols. However current protocols still utilize supra-physiological concentrations of gonadotropins resulting in variable outcomes, both in the number of ovulations and the quality of the oocytes particularly in cattle. Recently however, a single injection of a preparation of long-acting recombinant FSH (rbFSH) was shown to produce similar superovulatory responses, resulting in the production of good quality embryos, when compared with a pituitary-derived FSH preparation administered twice daily for 4 days (Carvalho et al., 2014). The authors concluded that more studies using different types of cattle and different doses of rbFSH are needed to confirm the findings reported in this preliminary study. In conclusion further work is still required.

\section{Intra-ovarian control}

Over the last two decades, much work has concentrated on the complex actions and interactions between locally produced hormones and growth factors (see Knight and Glister, 2003; Beg and Ginther, 2006; Webb and Campbell, 2007). Numerous interactions are involved in the control of follicle development during the early gonadotropin-independent stages of follicle development and are also involved in modulating the responsiveness of the follicle to gonadotropic signals during the later gonadotropin-responsive and gonadotropin-dependent stages of follicle development in monovular species. These systems include the insulin/IGF system (IGFs; Webb et al., 1999), the inhibin/activin system (Campbell and Baird, 2001; Campbell et al., 2003b) and the TGF- $\beta$ superfamily system (for example bone morphogenetic protein (BMPs), fibroblast growth factors (FGFs) and antiMüllerian hormone (Souza et al., 2002; Campbell et al., 2006; Monniaux et al., 2010; Chaves et al., 2012; see Fig. 2).

Moreover, contrary to previous understanding, the oocyte is not a passenger within the follicle as increasing evidence has shown that it is able to modulate follicular development through the production of several oocyte specific secreted factors, among which growth differentiation factor-9 (GDF9; Juengel et al., 2006), BMP15 (Galloway et al., 2000) and BMP6 (Knight and Glister, 2003, 2006; Campbell et al., 2006) are implicated (McNatty et al., 2007). Gap junctionmediated communication between the oocyte and the surrounding somatic cells is essential for the coordinated development of both cell types, including somatic cells providing the oocyte with metabolic substrates and meiosis-arresting signals (Themmen, 2005). The orderly, stage specific expression of this intrafollicular cascade, is essential for continuing and healthy ooctye and follicle development. One of the best described is the transition of the ovarian somatic cells, during the gonadotropin responsive phase, from a proliferative phenotype with a high mitotic index (MI) to a differentiative phenotype with low MI, increased levels of gonadotropin receptors, induction of steroidogenic enzymes and other endocrine and local factors (Webb and Campbell, 2007). 


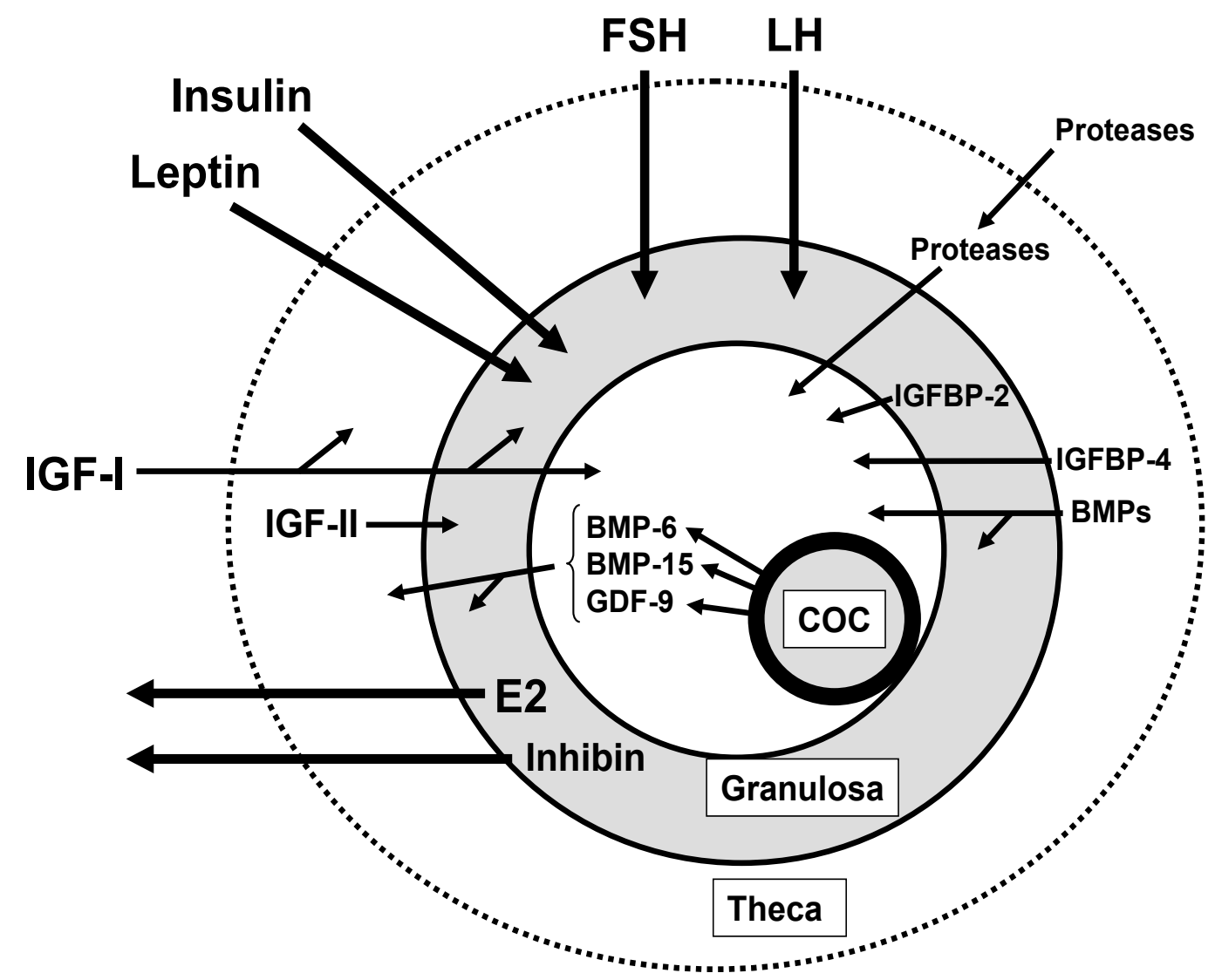

Figure 2. Peripheral gonadotropins and metabolic hormones work in conjunction with follicular growth factors (IGFs, IGFBPs, BMPs, GDF-9), released by granulosa, theca and the oocyte, to regulate development of the follicle and cumulus-oocyte complex (COC). Adapted from Garnsworthy et al. (2008).

\section{Insulin-like growth factors (IGFs)}

While carrying out studies to delineate the action of the classical gonadotropic hormones, there was an interesting result whereby dairy cows treated with recombinant growth hormone (bovine somatotropin; bST) to increase milk yield had significantly increased twinning rates (see Webb et. al., 1994). Importantly heifers given a dose of bST similar to that given to lactating dairy cows to increase milk yield (Gong et al., 1991) doubled the population of small antral follicles (2 to $5 \mathrm{~mm}$ in diameter), a finding that was subsequently confirmed in Bos indicus breeds (Buratini et al., 2000). Further studies (Gong et al., 1993a, 1997) demonstrated that (1) the number of small follicles were reduced as the dominant follicle grew and reached its maximum size; (2) bST could significantly enhance the recruitment of small follicles in heifers and that this increase was positively correlated with peripheral IGF-1 and insulin concentrations and (3) bST did not affect the turnover of follicular waves, nor the inhibitory action of the dominant follicle on its subordinate follicles. Hence bST can enhance the recruitment of small follicles through increases in peripheral concentrations of either IGF-1 and/or insulin concentrations. Indeed, pre-treatment of heifers with bST enhanced the superestimulatory response to pregnant mare serum gonadotropin or equine chorionic gonadotropin (PMSG-eCG)/FSH in terms of the number of ovulations, total number of ova/embryos recovered and number of transferable embryos. Importantly, the quality of embryos also appeared to be improved (Gong et al., 1993b, 1996).

These previous studies demonstrated that growth hormone, IGF-1 and insulin have a significant role in the reproductive axis, as well as in the classical metabolic axis where they stimulate longitudinal growth and enhance muscle mass. In vitro studies have also demonstrated the action of IGF-1 on cell proliferation and steroidogenesis in ruminants, but questioned whether IGF-1 is produced in physiologically significant quantities by granulosa cells (see Lucy, 2000; Webb and Campbell, 2007). These previous results and other studies (Armstrong et al., 2000) supported the hypothesis that theca-derived IGF-2 is the major intraovarian IGF ligand produced by bovine antral follicles. The expression of mRNA encoding type 1 IGF receptor in granulosa cells from preantral follicles, but before the developmental stage when IGF2 mRNA is expressed, suggested an endocrine role for IGFs in regulating preantral follicle growth.

As well as the IGF ligands and the receptors, binding proteins have also been shown to have a modulating role. The presence of at least 51 IGF binding protein (BP) isoforms corresponding to IGFBP1 to -6 , many of which were phosphorylated, were detected in bovine follicular fluid from subordinate follicles (Nicholas et al., 2002). The results also confirmed that the total number of IGFBPs was reduced 
in dominant follicles. This work demonstrated the high degree of conservation of IGFBP post-translational modifications between species. Furthermore, IGFBP-2 immunoactivity has been shown to be localized in bovine granulosa cells and the basement membrane of healthy preantral follicles, whereas IGFBP-4 immunoactivity was only localized in both theca and granulosa tissue (Armstrong et al., 1998). Of particular interest was the lack of IGFBP-2 mRNA expression in large $(>8 \mathrm{~mm})$ gonadotropin-dependent follicles Utilising serum-free cell culture systems, FSH was shown to inhibit the expression of IGFBP-2 mRNA in granulosa cells, whereas LH stimulated IGFBP-4 mRNA expression in theca cells. Furthermore a significant correlation was demonstrated between the presence of low molecular weight IGFBPs in bovine follicular fluid and caspase-3 activity of granulosa cells from individual follicles (Nicholas et al., 2005). In summary these results, along with others, demonstrate the central importance of the IGF system in ruminant follicular development and demonstrate avenues (see Fig. 2; Armstrong et al., 2003; Lucy, 2003) through which nutrition can impact on follicular development.

\section{Bone morphogenetic/growth differentiation factors (BMPs/GDFs)}

As discussed, these factors are mainly produced by the oocyte, pointing to the influence of these cells on follicular development (McNatty et al., 2007, 2014). Naturally occurring mutations in sheep and humans (Otsuka et al., 2011; Wang et al., 2013) of GDF9 (Hanrahan et al., 2004; Juengel et al., 2004; McNatty et al., 2007; Nicol et al., 2009; Otsuka et al., 2011; Wang et al., 2013), BMP15 (Galloway et al., 2000; McNatty et al., 2001; Souza et al., 2001; Wilson et al., 2001; Hanrahan et al., 2004; Juengel et al., 2004; Monteagudo et al., 2009; Otsuka et al., 2011) and their receptors (i.e. ALK6; Mulsant et al., 2001, Souza et al., 2001; Wilson et al., 2001), show increases in ovulation rates in these species. However, when mutations on GDF9 and/or BMP15 genes are homozygous, the ovaries do not show follicular development (i.e. streak ovaries; Hanrahan et al., 2004; Juengel et al., 2004; McNatty et al., 2007; Nicol et al., 2009). On histological examination, follicles in these animals are arrested at the primary stage, indicating that these factors are important signals for follicular development. Data from sheep shows clearly that the BMPs are ineffective in stimulating granulosa cell differentiation in the absence of FSH, but do reveal a clear interaction between the level of IGF and BMP exposure in terms of the induction of aromatase activity (Campbell et al., 2006; see Fig. 2). Thus, in this species both BMP and IGF act to augment FSHstimulated cellular differentiation.

In vitro and in vivo work, carried out in our laboratory, with BMP15 yielding equivocal results. Ovine granulosa cells treated with low doses of rhBMP15 alone showed mild increases in FSHstimulated estradiol production while higher doses were markedly inhibitory. Bone morphogenetic protein 15 is, however, known to form heterodimers with GDF9
(Mottershead et al., 2013) and exposure of granulosa cells to both rmGDF9 and rhBMP15 induced a 10-fold increase in estradiol production when compared to the same doses in isolation (A Marsh, J HernandezMedrano, BK Campbell, 2016; Dept Obstetrics and Gynaecology, University of Nottingham, UK, Faculty of Veterinary Medicine, UNAM, Mexico City, Mexico; University of Nottingham, Queen's Medical Centre, Nottingham, UK; unpublished results). Moreover, in vivo experiments in sheep using either in situ ovarian cannulation or an ovarian autotransplant model, showed that direct infusion of rhBMP15 resulted in small, but statistically significant increases in ovarian androstenedione and estradiol secretion. This was confirmed by direct ovarian infusion of antisera specific ovine BMP15 sequences (J Hernandez-Medrano, BK Campbell; 2016; Faculty of Veterinary Medicine, UNAM, Mexico City, Mexico; University of Nottingham, Queen's Medical Centre, Nottingham, UK; unpublished results). Therefore, the physiological importance of BMP15 in ruminant species appears more complex than indicated by the phenotypes observed in the sheep mutation carriers. However there is recent evidence (Behrouzi et al., 2016) that BMP15, GDF9, and TGF- $\beta 1$ can be up regulated in bovine preovulatory follicles, providing a possible link with improved pregnancy rates.

\section{Fibroblast growth factors (FGFs)}

Follicular development is regulated by a combination of inhibitory as well as stimulatory mechanisms. Evidence from in vivo and in vitro studies in cattle point to an anti-steroidogenic inhibitory role for FGFs (Chaves et al., 2012). Interestingly, the capacity to prevent or attenuate FGF action appears to be included in the various mechanisms leading to selection of the dominant follicle and its continued growth towards ovulation. In the bovine follicle wall, expression of FGF17 and FGF18, members of the FGF8 subfamily, is highest in atretic granulosa and theca cells, respectively. This expression pattern, combined with the inhibitory effects of FGF17 and FGF18 proteins on estradiol and progesterone production from cultured granulosa cells, suggest their involvement in paracrine/autocrine loops leading to follicular atresia (Machado et al., 2009; Portela et al., 2010). Alternatively, FGF10, a member of the FGF7 subfamily, appears to exert its inhibitory role in a different context. Several lines of evidence point to the participation of FGF10 in the regulation of follicle selection. Expression of FGF10 was detected in bovine oocytes and theca cells, where lower levels of the transcript were observed in healthy follicles. In contrast, FGF10 receptors (FGFR1B and FGFR2B) are expressed in both theca and granulosa cells at lower levels in healthy follicles. More importantly, FGF10 inhibited estradiol production from granulosa cells in vitro and when injected into the future dominant follicle, also blocked follicular growth (Buratini et al., 2007; Gasperin et al., 2012; Castilho et al., 2015). More recently, mRNA abundance of FGF10 was reported to be lower in the future dominant follicle compared with 
the largest subordinate follicle before morphological divergence, whilst levels of FGFR2B mRNA were higher in granulosa cells from the subordinate follicle (Castilho et al., 2015). Data from this study also indicate that the mechanisms by which FGF10 supress follicular steroidogenesis involve a reduction in the sensitivity of the follicle to FSH and IGFs, as FGF10 decreased mRNA abundance of FSHR and IGFR-1 in granulosa cells. The interaction between the FGF and IGF systems in the control of follicular development is further substantiated by the inhibitory effect of IGF1 on FGFR2B expression in granulosa cells (Buratini et al., 2007). Therefore, a feedback loop involving the FGF and IGF systems appears to be important for dominant follicle selection. The inhibition of the FGF10 system contributes to enhance IGF signalling, whilst IGF signalling attenuates the inhibitory influence of FGF10 in the future dominant follicle (see Fig. 3).
In addition to the regulation of steroidogenesis in the follicle wall, FGFs are expressed by the oocyte and appear to mediate oocyte-cumulus interactions in the antral follicle. When supplemented during in vitro maturation (IVM) of bovine cumulus-oocyte complexes, FGF10 enhanced cumulus expansion, while increasing PTGS2 expression and glucose uptake by cumulus cells. As glycolytic activity was not altered by FGF10, the increase in glucose uptake most likely provides more substrate for hyaluronic acid, thus leading to more exuberant expansion (Caixeta et al., 2013). Fibroblast growth factor 17 was also capable of enhancing cumulus expansion when added to the IVM medium, and interacted with BMP15 to increase embryo quality as measured by number of cells in the inner cell mass. In summary, the FGF system adds another level of complexity in the control of dominant follicle development.

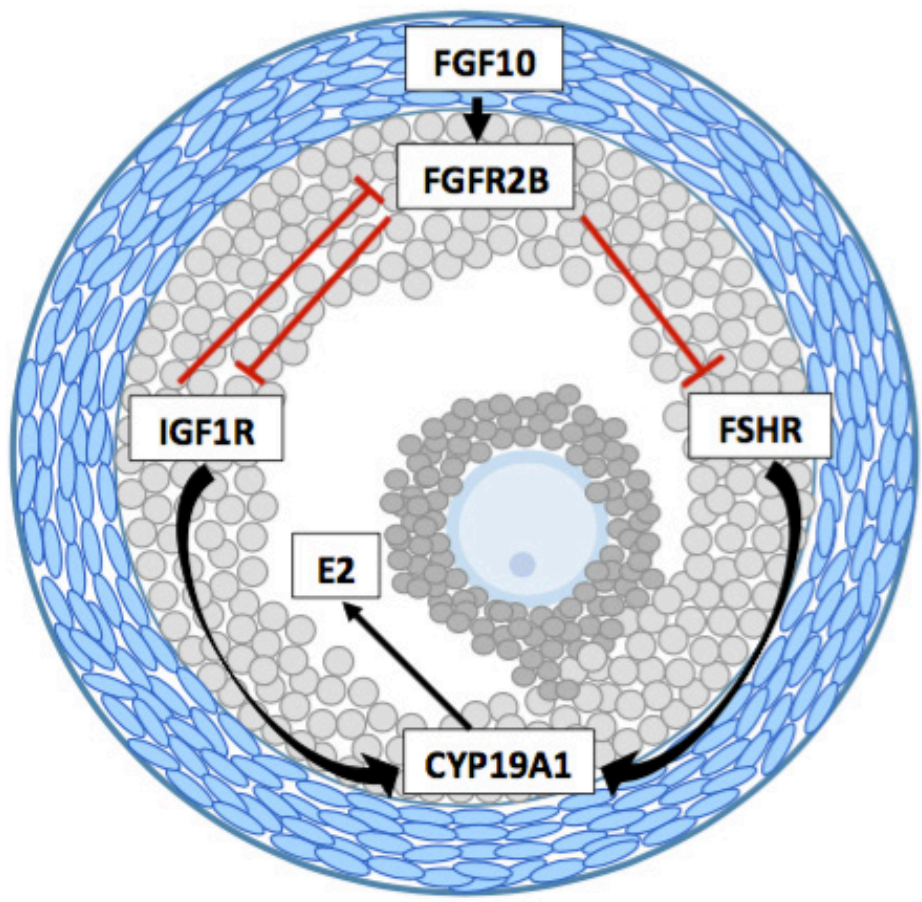

Figure 3. Proposed model for the participation of FGF10 in the control of estradiol production during follicle selection. FGF10/FGFR2B signaling is enhanced in the future subordinate follicle and decreases sensitivity to FSH and IGF, leading to a reduction in CYP19A1 expression and, consequently, estradiol production. The inhibition of IGF signaling by FGF10 would also contribute to enhance and prolong FGF10 signaling in the future subordinate follicle, as IGF signaling inhibits FGFR2B expression.

\section{Vascular endothelial growth factor (VEGF)}

Growth of the dominant follicle, and of the CL, also require the parallel growth of a capillary network to sustain them to ensure the supply of oxygen and trophic hormones. VEGF is a key signal that promotes angiogenesis and it is indispensable for the growth of antral follicles (Taylor et al., 2007; Robinson et al., 2009) and CL (Guzmán et al., 2014). However, as for the IGF-1 system, the VEGF system is complex and composed of two receptors and 6 ligand isoforms. It has been shown that VEGF mRNA, for isoforms 120, 164 and 205, are expressed in both granulsoa and theca cells. The inception of atresia was accompanied with disappearance of the expression of VEGF205 and a reduction in mRNA for VEGF164 and VEGF120 in granulosa cells. This was evident in theca cells in advanced stages of atresia (Rosales-Torres et al., 2010). In addition, protein and mRNA expression of the extracellular domain of the VEGF receptors has been reported in the dominant follicle. These soluble proteins are released to act extracellularly, to bind and block the action of VEGF. The expression of soluble VEGF receptor 1 (VEGF-R1) declines as the follicle grows. In contrast, the sVEGF-R2, which has higher affinity to the ligand, increases as the dominant follicle grows (Macias et al., 2012). This increase in an antagonistic soluble receptor could decrease follicle angiogenesis just prior 
to ovulation to avoid excessive bleeding at the ovulation site.

\section{Anti-Müllerian hormone (AMH)}

Among the factors implicated in early follicular development is AMH (Durlinger et al., 2002; Ireland et al., 2011; Campbell et al., 2012; Monniaux et al., 2014; Estienne et al., 2015). AMH is a dimeric glycoprotein member of the TGF- $\beta$ superfamily (Rey et al., 2003; van Houten et al., 2010; Monniaux et al., 2014) and produced in granulosa cells from the primary follicle stage, increasing in preantral and small antral follicles, and gradually decreasing in mid- to large-antral follicles (Rico et al., 2011; Campbell et al., 2012). AntiMüllerian hormone knock-out studies in mice (Durlinger et al., 2002) and sheep (Campbell et al., 2012) have reported increases in the number of developing follicles suggesting that $\mathrm{AMH}$ is involved in both the regulation of transition from primordial into primary follicles (Gigli et al., 2005) and the rate of progression of gonadotropin-responsive to the gonadotropin-dependent stage. Furthermore, recent studies of follicle number and AMH in cattle have concluded that the inherently high variation in the ovarian reserve (Mossa et al., 2012), which is both heritable (Walsh et al., 2014) and also affected by maternal undernutrition (Mossa et al., 2013), has a negative impact on ovarian function that may result in suboptimal fertility (Ireland et al., 2011). Furthermore it appears that $\mathrm{AMH}$ measurement can be used to assess fertility in cattle, as AMH is linked to follicle number (Monniaux et al., 2010; Ireland et al., 2011).

Regarding the mechanism of action, AMH has been shown to inhibit gonadotropin dependent growth of cultured mouse preantral follicles (Durlinger et al., 2002; Themmen, 2005; Bertold et al., 2016) and in rat, pig and sheep granulosa cell cultures, AMH attenuates the FSH-dependent increase in aromatase activity (see Fig. 4), estrogen synthesis/release and LH receptor expression (di Clemente et al., 1994; HernandezMedrano et al., 2012). Additionally, recent in vitro observations have demonstrated that $\mathrm{AMH}$ is a potent inhibitor of LH-stimulated androgen production in theca cells. This was supported by increasing concentrations of androstenedione in follicular fluid observed in small antral follicles following immunisation against $\mathrm{AMH}$ in sheep. Furthermore, AMH concentrations have been shown to increase in vitro (Elfituri, 2016) and in vivo (Narkwichean et al., 2014) following treatment of granulosa cells and ewes, respectively, with aromatisable and non-aromatisable androgens, thus providing further evidence that androgens may have a direct role in the regulation of $\mathrm{AMH}$ production. Further, the observation that readily diffusible VEGF variants associated with growing follicles (VEGF120 and VEGF164) act as negative regulators of granulosa cell AMH expression support a model whereby AMH may be central to the development of thecal cell function in gonadotropin responsive follicles, both in terms of steroidogenesis and angiogenesis. Figure 5 outlines a proposed model of the control of AMH expression in granulosa cells under the stimulatory influence of oocyte secreted factors (GDF9 and BMP15) and diffusion gradients originating from the oocyte and inhibitory influence of thecal cell derived androgen.

In conclusion there are a range of intra-ovarian factors that act at all stages of follicular development in concert with gonadotropin drive. These complex, and possibly, redundant systems ensure that the dominant follicle will produce a quality oocyte at ovulation. They also highlight the various sites whereby extra-ovarian and environmental factors can impact on ovarian function and follicular development.

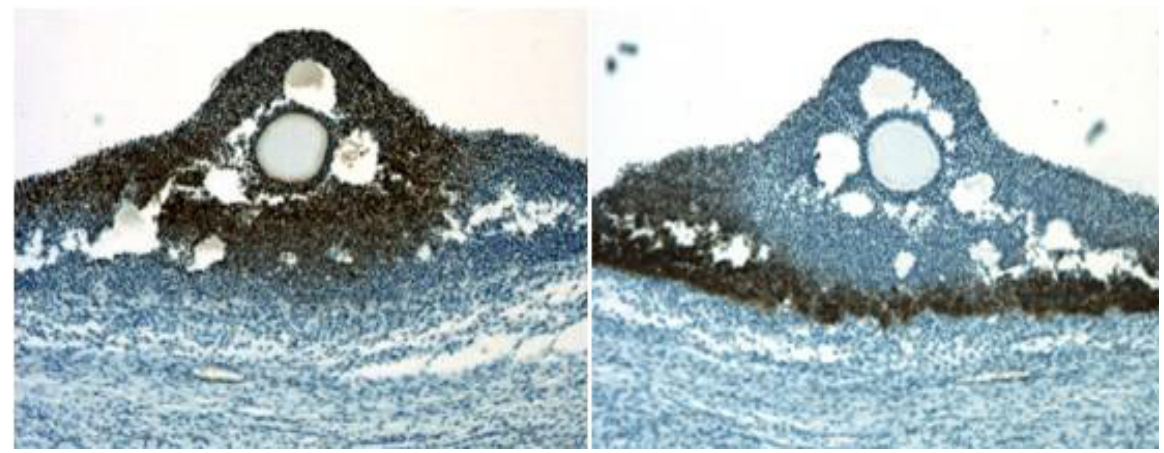

Figure 4. Expression of AMH (left) and Aromatase (right) protein in consecutive sections from the same gonadotropin-dependent large antral sheep follicle. Note AMH expression is absent from the differentiated granulosa cell layer but present in coronal/cumulus cells surrounding the oocyte and is directly inverse to aromatase expression. Adapted from Campbell et al. (2012). 


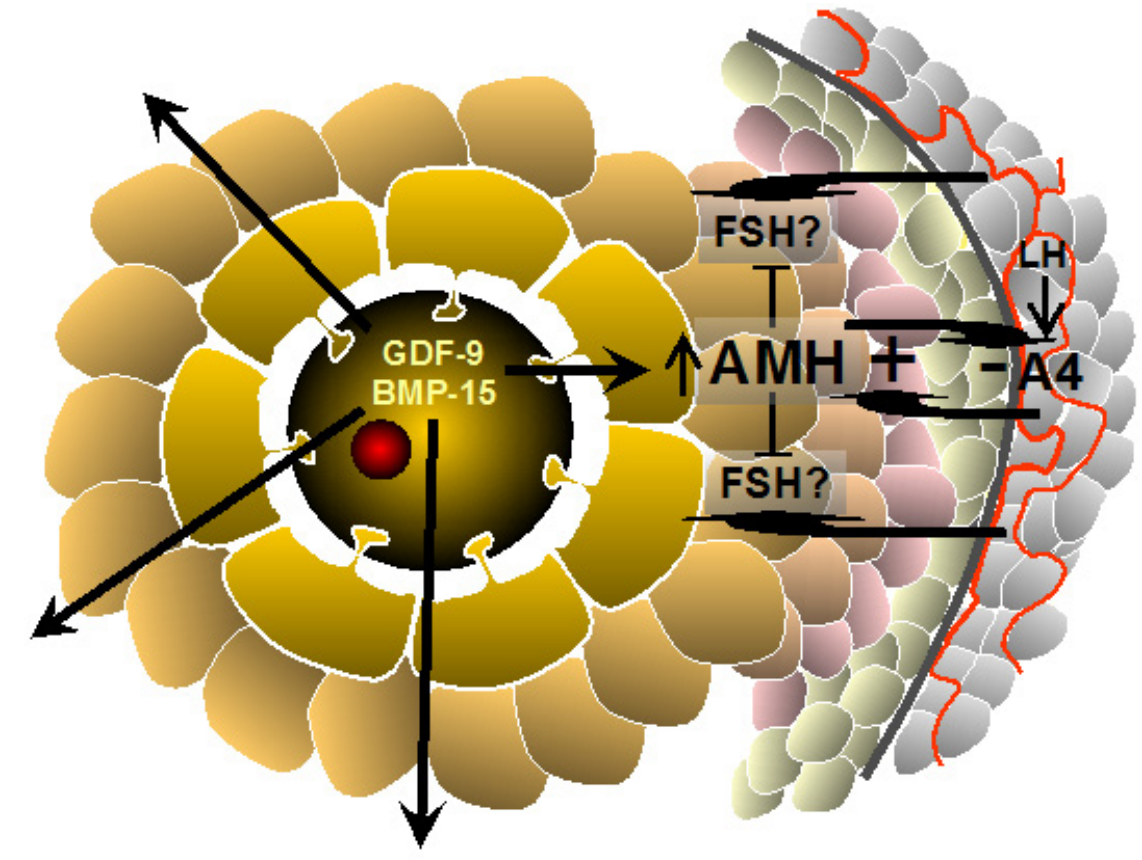

Figure 5. Proposed model of control of AMH expression in granulosa cells under the stimulatory influence of oocyte secreted factors and diffusion gradients. These originate from the oocyte. Also note the inhibitory influence of thecal cell derived androgen. Adapted from Campbell et al. (2014).

\section{Nutritional influences}

As discussed, even though follicular and oocyte development occurs as a sequence of well-synchronised events, they are susceptible to environmental interferences. This is clear from the effect that growth hormone, working via IGFs and insulin, can influence follicular development and oocyte quality (see Buratini et al., 2000; Webb and Campbell, 2007; Sartori et al., 2013). Indeed the response of domestic animals to their environment is an important determinant of reproductive efficiency. Environmental influences such as temperature, and the quantity and quality of food all impinge on various facets of reproductive function.

Nutritional supplementation has long been known to improve reproductive performance and to enhance the lambing rate of sheep and goat flocks (Scaramuzzi and Martin, 2008; Martin, 2009). As early as 1899 (Heape, 1899) it was recognized that fatter sheep, or sheep with higher nutritional intake produced a higher proportion of twin lambs. Subsequent studies have confirmed that as body weight of the ewe increases, there is also an increase in the ovulation and subsequent twinning rate (Coop, 1962; Morley et al., 1978). Furthermore three decades ago in beef cattle, it was shown that calving cows in a higher body condition have improved reproductive performance (Wright et al., 1987).

In comparison with cattle, follicular waves in small ruminants are not as clearly spaced. Furthermore, sheep and goats appear to have follicles capable of reaching maturity and ovulating within 60 to $80 \mathrm{~h}$, when luteolysis is induced at any time of the estrous cycle. These observations led to the concept that the period required to achieve an increase in ovulation rate by flushing need not be longer than the length of the recruitment phase, if given at a time where follicles predestined for ovulation are selected (Gutierrez et al., 2011). The precise requirement for this stimulus seems to be the period of increased LH pulse frequency, following decline in progesterone concentrations. Indeed, short term flushing prior to luteolysis increases ovulation rate when given either as an oral glycogenic substance (Letelier et al., 2008; Gutierrez et al., 2011), or when lupin grains are added to the diet (Downing et al., 1995; Muñoz-Gutierrez et al., 2004), or by intravenous infusion of either glucose (Muñoz-Gutierrez et al., 2002; Gallet et al., 2009) or glucosamine (Muñoz-Gutierrez et al., 2002). The increase in ovulation rate seems to be related to an increase in glucose, insulin and leptin concentrations, but without detectable changes in peripheral IGF-1 or FSH (Viñoles et al., 2005).

In further studies, the period of flushing was shortened to a single oral drench, using soluble substrates that acutely increase propionic acid in the rumen and glucose concentrations in blood (Ferraro et al., 2009, 2016). In addition, the effect of these substances was short-lived, limiting the effect to a defined period of time. In two studies, glucogenic drenching, at the time of either luteolysis or progestin withdrawal, increased ovulation rate in sheep, with around $90 \%$ of ewes having multiple ovulations (see Table 1; Gutierrez et al., 2011). The increase in ovulation rate may be due to an increase in circulating concentrations of insulin, but not IGF-I, that lasted for $12 \mathrm{~h}$ after drenching (Martinez, 2004; Ferraro et al., 2016). In addition, the rise in ovulation rate was not accompanied by an increase in the number of small $(<4$ $\mathrm{mm})$ and large $(>4 \mathrm{~mm})$ follicles, nor was the diameter of the three largest follicles affected. However, there was a decrease in the number of mRNA transcripts for 
P450 aromatase, with no changes in either the LH receptor or $3 \beta$-HSD (Ferraro, 2011). These studies confirm, in sheep, that the twelve hours following luteolysis are fundamental, not only for the selection of ovulatory follicles and the determination of ovulation rate, but that this period of development is very sensitive to the impact of environmental factors such as nutrition.

Table 1. Frequency of multiple ovulations in Pelibuey ewes treated with oral administration of a glycogenic solution $(300 \mathrm{ml}$ of glycerol: water solution; $90: 10 \mathrm{v} / \mathrm{v})$ at the time of estrous synchronization with PGF2 $\alpha$ or FGA+ PGF2 $\alpha$.

\begin{tabular}{|c|c|c|c|c|c|c|}
\hline \multirow{2}{*}{ Treatment group } & \multirow{2}{*}{$\mathrm{N}$} & \multicolumn{4}{|c|}{ Ovulation type (\%) } & \multirow{2}{*}{ Ovulation rate } \\
\hline & & Single & Double & Triple & Quadruple & \\
\hline \multicolumn{7}{|l|}{ Synchronisation with PGF $2 \alpha$} \\
\hline Control $^{\mathrm{a}}$ & 58 & 39.66 & 60.34 & 0 & 0 & $1.6 \pm 0.06^{\mathrm{a}}$ \\
\hline Glycerol $^{b}$ & 74 & 10.81 & 71.62 & 16.22 & 1.35 & $2.08 \pm 0.06^{\mathrm{b}}$ \\
\hline \multicolumn{7}{|c|}{ Synchronisation with progestins } \\
\hline Control $^{\mathrm{a}}$ & 55 & 39.62 & 56.60 & 3.77 & 0 & $1.64 \pm 0.07^{\mathrm{a}}$ \\
\hline Glycerol $^{\mathrm{b}}$ & 53 & 5.66 & 50.94 & 39.62 & 3.77 & $2.41 \pm 0.09^{\mathrm{b}}$ \\
\hline
\end{tabular}

$\overline{a, b}$ Different superscripts within a column differ $(\mathrm{P}<0.01)$. From Gutierrez et al., 2016; Faculty of Veterinary Medicine, UNAM, Mexico City, Mexico; unpublished observations.

Despite the recent improvement in reproductive performance of high-yielding dairy cows, promoted by both pharmacological control of follicular growth and ovulation for fixed time AI and genetic improvements, reduced fertility still has major implications for economic sustainability (Chagas et al., 2007; Wiltbank et al., 2011). In the case of high-yielding dairy cows reproductive performance had been declining for a number of decades due to the selection for increased milk yield (Royal et al., 2000), especially when animals are under negative energy balance (Butler, 2003). Energy balance is defined as energy intake minus energy output in milk. If energy intake is insufficient to meet the demands of milk secretion, as it usually is in early lactation, body reserves are mobilized. If energy intake exceeds requirements, excess energy is deposited as body fat, but over the long-term cows can adjust their energy intake in an attempt to keep levels of body energy reserves constant (Garnsworthy, 1988; Garnsworthy and Webb, 1999). In postpartum beef cows recent results demonstrated that an increase in lean tissue, in relation to body fat, can result in diminished serum concentrations of leptin and IGF-1 (Guzman et al., 2016). These hormonal changes compromise the response to estrus induction resulting in reduced estrus and estrous cycles after treatment, and pregnancies at the end of the breeding period, further demonstrating the interrelationship between the classical metabolic hormones and reproductive function.

In dairy cattle there has been significant research effort worldwide to both elucidate the underlying mechanisms and to devise nutritional strategies that can maintain milk production and quality, while stimulating dominant follicle development, maintaining oocyte quality and hence improving fertility. From the previous discussion it is clear that because of the interactions between extra- and intraovarian regulatory systems an integrated approach is required, because changes in one system can impact on other systems. There is also a requirement to consider general homeostatic and homeorhetic mechanisms simultaneously with the mechanisms involved in the initiation of ovarian cycles postpartum, development of the dominant follicle and the production of a good quality oocyte. For example, high insulin diets that result in higher peripheral insulin concentrations result in a significantly higher number of poor quality oocytes (Adamiak et al., 2005), whereas the addition of fat to a high-starch diet improved blastocyst yield (FouladiNashta et al., 2007). In a large series of studies (see Garnsworthy et al., 2008), based on our increased understanding of the factors affecting follicular development and oocyte quality, it was demonstrated that the optimum strategy for improving fertility in high-yielding dairy cows was initially to feed a diet that stimulated follicular development and then to feed a diet that improved the developmental competence of oocytes (Garnsworthy et al., 2009). This information is now being applied within the UK dairy industry, in conjunction with genetic fertility index information, to reverse the previous long-term decline in fertility of high yielding dairy cows. However, as reviewed and concluded by Leroy et al., (2013), further work is required to elucidate both the direct and indirect effects of dietary lipid supplementation on oocyte quality and pregnancy rates.

\section{Conclusions}

Over the last half-century our understanding of the control of follicle development and selection in ruminants has increased immeasurably with the application of a range of new technologies. This has resulted in the realization that follicular development and selection of the dominant follicle and the production of a good quality oocyte are controlled by a set of complex and interactive systems, including (i) the requirement for continuous gonadotropic drive in the later stages of development, (ii) the interaction of a range of local intraovarian growth factor systems and (iii) genetic and environmental influences. A plethora of studies worldwide, have shown that this increased 
understanding can result in improved fertility, as demonstrated by the impact of diet on oocyte quality and increased pregnancy rates. Importantly, continuing improvements in the reproductive performance of domestic ruminants will require further increased understanding of these multifactorial mechanisms that control ovarian follicle development. For example, there will be opportunities as new understanding and new technologies are developed, as demonstrated by the identification of alleles that could be beneficial for estrous behavior and hence provide an opportunity for selection of cows displaying stronger estrous activity (Homer et al., 2013).

In conclusion, despite significant progress there is still a need for improved estrous detection and conception rates, reduced embryo loss and the ability to control superstimulatory responses more precisely. These are livestock production issues that were present over 50 years ago and which have become even more important to improve further given the increasing global challenges of food security and climate change.

\section{Acknowledgments}

Carlos G. Gutierrez thanks DGAPA, UNAM for support towards a sabbatical visit.

\section{References}

Adamiak SJ, Mackie K, Watt RG, Webb R, Sinclair KD. 2005. Impact of nutrition on oocyte quality: cumulative effects of body composition and diet leading to hyperinsulinemia in cattle. Biol Reprod, 73:918-926.

Adams GP. 1999. Comparative patterns of follicle development and selection in ruminants. $J$ Reprod Fertil Suppl, 54:17-32.

Asdell SA. 1960. Growth of the bovine Graafian follicle. Cornell Vet, 50:3-9.

Armstrong DG, Baxter G, Gutierrez CG, Hogg CO, Glazyrin AL, Campbell BK, Bramley TA, Webb R. 1998. Insulin-like growth factor binding protein-2 and 4 messenger ribonucleic acid expression in bovine ovarian follicles: effect of gonadotropins and developmental status. Endocrinology, 139:2146-2154.

Armstrong DG, Gutierrez CG, Baxter G, Glazyrin AL, Mann GE, Woad KJ, Hogg CO, Webb R. 2000. Expression of mRNA encoding IGF-I, IGF-II and type 1 IGF receptor in bovine ovarian follicles. $J$ Endocrinol, 165:101-113.

Armstrong DG, Gong JG, Webb R. 2003. Interactions between nutrition and ovarian activity in cattle: physiological, cellular and molecular mechanisms. Reproduction Suppl, 61:403-414.

Baird DT, Campbell BK, Mann GE, McNeilly AS. 1991. Inhibin and oestradiol in the control of FSH in the sheep. J Reprod Fertil Suppl, 43:125-138.

Baird DT, Webb R, Campbell BK, Harkness LM, Gosden RG. 1999. Long-term ovarian function in sheep after ovariectomy and transplantation of autografts stored at $-196^{\circ} \mathrm{C}$. Endocrinology, 140:462-471.

Bane A, Rajakoski E. 1961. The bovine estrous cycle. Cornell Vet, 51:77-95.
Bao B, Garverick HA, Smith GW, Smith MF, Salfen BE, Youngquist RS. 1997. Changes in messenger ribonucleic acid encoding luteinizing hormone receptor, cytochrome P450-side chain cleavage, and aromatase are associated with recruitment and selection of bovine ovarian follicles. Biol Reprod, 56:1158-1168.

Bao B, Garverick HA. 1998. Expression of steroidogenic enzyme and gonadotropin receptor genes in bovine follicles during ovarian follicular waves: a review. J Anim Sci, 76:1903-1921.

Behrouzi A, Colazo MG, Ambrose DJ. 2016. Alterations in bone morphogenetic protein 15, growth differentiation factor 9 , and gene expression in granulosa cells in preovulatory follicles of dairy cows given porcine LH. Theriogenology, 85:1249-1257.

Beg MA, Bergfelt DR, Kot K, Wiltbank MC, Ginther OJ. 2001. Follicular-fluid factors and granulosa-cell gene expression associated with follicle deviation in cattle. Biol Reprod, 64:432-441.

Beg MA, Ginther OJ. 2006. Follicle selection in cattle and horses: role of intrafollicular factors. Reproduction 132:365-377.

Bertoldo MJ, Bernard J, Duffard N, Tsikis G, Alves S, Calais L, Uzbekova S, Monniaux D, Mermillod P, Locatelli Y. 2016. Inhibitors of c-Jun phosphorylation impede ovine primordial follicle activation. Mol Hum Reprod, 22:338-349.

Buratini Jr J, Price CA, Visintin JA, Bó GA. 2000. Effects of dominant follicle aspiration and treatment with recombinant bovine somatotropin (BST) on ovarian follicular development in Nelore (Bos indicus) heifers. Theriogenology, 54:421-431.

Buratini Jr J, Pinto MGL, Castilho AC, Amorim RL, Giometti IC, Portela VM, Nicola ES, Price CA. 2007. Expression and function of fibroblast growth factor 10 and its receptor, fibroblast growth factor receptor 2B, in bovine follicles. Biol Reprod, 77:743750 .

Butler WR. 2003. Energy balance relationships with follicular development, ovulation and fertility in postpartum dairy cows. Livest Prod Sci, 83:211-218.

Caixeta ES, Sutton-McDowall ML, Gilchrist RB, Thompson JG, Price CA, Machado MF, Lima PF, Buratini J. 2013. Bone morphogenetic protein 15 and fibroblast growth factor 10 enhance cumulus expansion, glucose uptake, and expression of genes in the ovulatory cascade during in vitro maturation of bovine cumulusoocyte complexes. Reproduction, 146:27-35.

Campbell BK, Scaramuzzi RJ, Webb R. 1995. The control of antral follicle development and selection in sheep and cattle. J Reprod Fertil Suppl, 49:335-350.

Campbell BK, Scaramuzzi RJ, Webb R. 1996. Induction and maintenance of oestradiol and immunoreactive inhibin production with $\mathrm{FSH}$ by ovine granulosa cells cultured in serum free medium. $J$ Reprod Fertil, 106:7-16.

Campbell BK, Baird DR, Webb R. 1998. Effects of dose of LH on androgen production and luteinization of ovine theca cells cultured in a serum-free system. $J$ Reprod Fertil, 112:69-77.

Campbell BK, Baird DT. 2001. Inhibin A is a follicle stimulating hormone-responsive marker of granulosa 
cell differentiation, which has both autocrine and paracrine actions in sheep. J Endocrinol, 169:333-345.

Campbell BK, Baird DT, Souza CJH, Webb R. 2003a. The Fec(B) (Booroola) gene acts at the ovary: in vivo evidence. Reproduction, 126:101-111.

Campbell BK, Souza C, Gong J, Webb R, Kendall N, Marsters P, Robinson G, Mitchell A, Telfer EE, Baird DT. 2003b. Domestic ruminants as models for the elucidation of the mechanisms controlling ovarian follicle development in humans. Reproduction Suppl, 61:429-443.

Campbell BK, Souza CJ Skinner AJ, Webb R, and Baird DT. 2006. Enhanced response of granulosa and theca cells from sheep carriers of the FecB mutation in vitro to gonadotropins and bone morphogenic protein-2, -4, and -6. Endocrinology, 147:1608-1620.

Campbell BK, Clinton M, Webb R. 2012. The role of anti-Mullerian hormone (AMH) during follicle development in a monovulatory species (sheep). Endocrinology, 153:4533-4543.

Campbell BK, Hernandez-Medrano J, McNeilly AS, Webb R, Picton HM. 2014. Ovarian function in domestic ruminants: mechanistic and translational aspects. In: Juengel JL, Miyamoto A, Price C, Reynolds LP, Smith MF, Webb, R (Ed.). Reproduction in Domestic Ruminants VIII. Ashby de la Zouch, UK: Context Publishing. pp. 359-373.

Carvalho PD, Hackbart KS, Bender RW, Baez GM, Dresch AR, Guenther JN, Souza AH, Fricke PM. 2014. Use of a single injection of long-acting recombinant bovine $\mathrm{FSH}$ to superovulate Holstein heifers: a preliminary study. Theriogenology, 82:481489.

Castilho ACS, Price CA, F. Dalanez F, Ereno RL, Machado MF, Barros CM, Gasperin BG, Gonçalves PBD, Buratini J. 2015. Evidence that fibroblast growth factor 10 plays a role in follicle selection in cattle. Reprod Fertil Dev. doi: 10.1071/RD15017.

Chagas LM, Bass JJ, Blache D, Burke CR, Kay J, Lindsay DR, Lucy MC, Martin GB, Meier S, Rhodes FM, Roche JR, Thatcher WW, Webb R. 2007. New perspectives on the roles of nutrition and metabolic priorities in the subfertility of high-producing cows. $J$ Dairy Sci, 90:4022-4032.

Chaves RN, Matos MH, Buratini Jr J, Figueiredo JR. 2012. The fibroblast growth factor family: involvement in the regulation of folliculogenesis. Reprod Fertil Dev, 24:905-915.

Coop IE. 1962. Liveweight-productivity relationships in sheep. NZJ Agric Res, 5:249-264.

Cupps PT, Laben RC, Mead SW. 1959. Histology of pituitary, adrenal and reproductive organs in norma cattle and cattle with lowered reproductive efficiency. Hilardia, 29:383-410.

di Clemente N, Goxe B, Remmy J, Cate R, Josso N, Vigier B. 1994. Inhibitory effect of AMH upon the expression of aromatase activity and LH receptors by cultured granulosa cells of rat and porcine immature ovaries. Endocrinology, 2:553-558.

Downing JA, Joss J, Connell P, Scaramuzzi RJ. 1995. Ovulation rate and the concentrations of gonadotrophic and metabolic hormones in ewes fed lupin grain. J Reprod Fertil, 103:137-145.

Driancourt MA, Webb R, Fry RC. 1991. Does follicular dominance occur in ewes? J Reprod Fertil, 93:63-70

Durlinger AL, Visser JA, Themmen JA. 2002. Regulation of ovarian function: the role of antiMullerian hormone. Reproduction, 124:601-609.

Elfituri A. 2016. Investigating the regulatory role of Anti-Müllerian hormone in the growing follicles of a monovulatory species. Nottingham, UK: University of Nottingham. Thesis (PhD).

England BG, Dahmer MK, Webb R. 1981. Relationships between follicular size and antral fluid steroid concentrations at three stages of the estrous cycle in the ewe. Biol Reprod, 24:1068-1076.

Estienne A, Pierre A, di Clemente N, Picard JY, Jarrier P, Mansanet C, Monniaux D, Fabre S. 2015. Anti-Mullerian hormone regulation by the bone morphogenetic proteins in the sheep ovary: deciphering a direct regulatory pathway. Endocrinology, 156:301313.

Ferraro SM, Mendoza GD, Miranda LA, Gutiérrez CG. 2009. In vitro gas production and ruminal fermentation of glycerol, propylene glycol and molasses. Anim Feed Sci Technol, 154:112-118.

Ferraro SM. 2011. Estudio de los mecanismos moleculares y endocrinos involucrados en la regulación de la tasa ovulatoria en ovejas por administración de una solución glucogénica. Ciudad de Mexico: Facultad de Medicina Veterinaria y Zootecnia, UNAM. Tesis (Doctorado en Ciencias).

Ferraro SM, Mendoza GD, Miranda LA, Gutiérrez CG. 2016. In vitro ruminal fermentation of glycerol, propylene glycol and molasses combined with forages and their effect on glucose and insulin blood plasma concentrations after an oral drench in sheep. Anim Feed Sci Techol, 213:74-80.

Fouladi-Nashta AA, Alberio R, Kafi M, Nicholas B, Campbell KHS, Webb R. 2005. Differential staining combined with TUNEL labelling to detect apoptosis in preimplantation bovine embryos. Reprod Biomed Online, 10:497-502.

Fouladi-Nashta AA, Gutierrez CG, Gong JG, Garnsworthy PC, Webb R. 2007. Impact of dietary fatty acids on oocyte quality and development in lactating dairy cows. Biol Reprod, 77:9-17.

Gallet C, Dupont J, Monniaux D, Campbell BK, Scaramuzzi RJ. 2009. The infusion of glucose reduces circulating concentrations of oestradiol and the level of aromatase in granulosa cells of ewes in the luteal phase of the oestrous cycle. In: Proceedings of the 11th International Symposium on Ruminant Physiology, 2009, Clermont, Francia. Clermont, France: ISRP. pp.742-743.

Galloway SM, McNatty KP, Cambridge LM, Laitinen MPE, Juengel JL, Sakari T, Robert J, McLaren J, Luiro K, Dodds KG, Montgomery GW, Beattie AE, Davis GH, Ritvos O. 2000. Mutations in an oocyte-derived growth factor gene (BMP15) cause increased ovulation rate and infertility in a dosagesensitive manner. Nat Genet, 25:279-283.

Garnsworthy PC. 1988. The effect of energy reserves 
at calving on performance of dairy cows. In: Garnsworthy PC (Ed.). Nutrition and Lactation in Dairy Cow. London: Butterworths. pp. 157-170.

Garnsworthy PC, Webb R. 1999. The influence of nutrition on fertility in dairy cows. In: Garnsworthy PC, Wiseman J (Ed.). Recent Advances in Animal Nutrition. Cambridge, UK: Nottingham University Press. pp. 3958.

Garnsworthy PC, Sinclair KD, Webb R. 2008. Integration of physiological mechanisms that influence fertility in dairy cows. Animal, 2:1144-1152.

Garnsworthy PC, Fouladi-Nashta AA, Mann GE, Sinclair KD, Webb R. 2009. Effect of dietary-induced changes in plasma insulin concentrations during the early post partum period on pregnancy rate in dairy cows. Reproduction, 137:759-768.

Garverick HA, Baxter G, Gong JG, Armstrong DG, Campbell BK, Gutierrez CG, Webb R. 2002. Regulation of expression of ovarian mRNA encoding steroidogenic enzymes and gonadotrophin receptors by FSH and GH in hypogonadotrophic cattle. Reproduction, 123:651-661

Gasperin BG, Ferreira R, Rovani MT, San JT, Buratini J, Price CA, Bayard P, Gonc, alves D. 2012. FGF10 inhibits dominant follicle growth and estradiol secretion in vivo in cattle. Reproduction, 143:815-823.

Gigli I, Cushman RA,Wahl CM, Fortune JE. 2005. Evidence for a role for anti-Mullerian hormone in the suppression of follicle activation in mouse ovaries and bovine ovarian cortex grafted beneath the chick chorioallantoic membrane. Mol Reprod Dev, 71:480-488. Ginther OJ, Wiltbank MC, Fricke PM, Gibbons JR, Kot K. 1996. Selection of the dominant follicle in cattle. Biol Reprod, 55:1187-1194.

Ginther OJ, Beg MA, Donadeu FX, Bergfelt DR. 2003. Mechanism of follicle deviation in monovular farm species. Anim Reprod Sci, 78:239-257.

Gong JG, Bramley TA, Webb R. 1991. The effects of recombinant bovine somatotropin on ovarian function in heifers: follicle populations and peripheral hormones. Biol Reprod, 45:941-94.

Gong JG, Bramley TA, Webb R. 1993a. The effect of recombinant bovine somatotrophin on ovarian follicular growth and development in heifers. J Reprod Fertil, 97:247-254.

Gong JG, Bramley TA, Wilmut I, Webb R. 1993b. Effect of recombinant bovine somatotropin on the superovulatory response to pregnant mares serum gonadotropin in heifers. Biol Reprod, 48:1141-1149.

Gong J G, Bramley TA, Gutierrez CG Peters AR, Webb R. 1995. Effects of chronic treatment with a gonadotrophin-releasing hormone agonist on peripheral concentrations of FSH and $\mathrm{LH}$, and ovarian function in heifers. J Reprod Fertil, 105:263-270.

Gong JG, Wilmut I, Bramley TA, Webb R. 1996. Pretreatment with recombinant bovine somatropin enhances the superovulatory response to FSH in heifers. Theriogenology, 46:611-622.

Gong JG, Baxter G, Bramley TA, Webb R. 1997. Enhancement of ovarian follicle development in heifers by treatment with recombinant bovine somatotrophin: a dose-response study. J Reprod Fertil, 110:91-97.
Gosden RG, Baird DT, Wade JC, Webb R. 1994. Restoration of fertility to oophorectomized sheep by ovarian autografts stored at $-196^{\circ} \mathrm{C}$. Hum Reprod, 9:597-603.

Gregson E, Webb R, Sheldrick EL, Campbell BK, Mann GE, Liddell S, Sinclair KD. 2016. Molecular determinants of a competent bovine corpus luteum: first vs final wave dominant follicles. Reproduction, 151:563-575.

Gutierrez CG, Campbell BK, Armstrong DG, Webb R. 1997a. Insulin-like growth factor-I (IGF-I) production by bovine granulosa cells in vitro and peripheral IGF-I measurement in cattle serum: an evaluation of IGF-binding protein extraction protocols. J Endocrinol, 153:231-240.

Gutierrez CG, Campbell BK, Webb R. 1997b. Development of a long-term bovine granulosa cell culture system: Induction and maintenance of estradiol production, response to follicle-stimulating hormone, and morphological characteristics. Biol Reprod, 56:608616.

Gutierrez CG, Ralph JH, Telfer EE, Wilmut I, Webb R. 2000. Growth and antrum formation of bovine preantral follicles in long-term culture in vitro. Biol Reprod, 62:1322-1328.

Gutierrez CG, Ferraro S, Martinez V, Saharrea A, Cortez C, Lassala A, Basurto H, Hernandez J. 2011. Increasing ovulation quota: more than a matter of energy. Acta Sci Vet Suppl, 39:305-316.

Guzmán A, Macías-Valencia R, Fierro-Fierro F, Gutiérrez CG, Rosales-Torres AM. 2014. The corpora lutea proangiogenic state of VEGF system components is turned to antiangiogenic at the later phase of the oestrous cycle in cows. Animal, 9:301-307.

Guzmán A, Gonzalez-Padilla E, Garcés-Yepez P, Rosete-Fernández JV, Calderón-Robles RC, Whittier WD, Keisler DH, Gutierrez CG. 2016. Increased body condition score through increased lean muscle, but not fat deposition, is associated with reduced reproductive response to oestrus induction in beef cows. Animal, 8 pp. doi:10.1017/S175173111600063X.

Hammond J. 1927. The Physiology of Reproduction in the Cow. Cambridge, UK: Cambridge University Press.

Hanrahan JP. 2003. Aspects of reproductive performance in small ruminants: opportunities and challenges. Reproduction Suppl, 61:15-26.

Hanrahan JP, Gregan SM, Mulsant P, Mullen M, Davis GH, Powell R, Galloway SM. 2004. Mutations in the genes for oocyte-derived growth factors GDF9 and BMP15 are associated with both increased ovulation rate and sterility in Cambridge and Belclare sheep (Ovis aries). Biol Reprod, 70:900-909.

Hauger RL, Karsch FJ, Foster DL. 1977. A new concept for the control of the estrous cycle of the ewe based on the temporal relationships between luteinizing hormone, estradiol and progesterone in peripheral serum and evidence that progesterone inhibits tonic $\mathrm{LH}$ secretion. Endocrinology, 101:807-817.

Heape W. 1899. Abortion, barrennes and fertility in sheep. J Royal Agric Soc, 10:217-248.

Hernandez-Medrano JH, Marsters P, Campbell BK. 
2012. Anti-Mullerian Hormone (AMH) knockdown increases steroidogenesis in ovine granulosa cells from small antral follicles in vitro. Biol Reprod, 87(suppl. 1):367-367.

Homer EK, Derecka K, Webb R, Garnsworthy PC. 2013. Mutations in genes involved in oestrous cycle associated expression of oestrus. Anim Reprod Sci, 142:106-112.

Ireland JJ, Coulson PB, Murphree RL. 1979. Follicular development during four stages of the estrous cycle in beef cattle. J Anim Sci, 49:1261-1269.

Ireland JJ, Roche JF. 1983 Development of nonovulatory antral follicles in heifers: changes in steroids in follicular fluid and receptors for gonadotropins. Endocrinology, 112:150-156.

Ireland JJ, Smith GW, Scheetz D, Jimenez-Krassel F, Folger JK, Ireland JLH, Mossa F, Lonergan P, Evans ACO. 2011. Does size matter in females? An overview of the impact of the high variation in the ovarian reserve on ovarian function and fertility, utility of anti-Mullerian hormone as a diagnostic marker for fertility and causes of variation in the ovarian reserve in cattle. Reprod Fertil Dev, 23:1-14.

Juengel JL, Bodensteiner KJ, Heath DA, Hudson NL, Moeller CL, Smith P, Galloway SM, Davis GH, Sawyer HR, McNatty KP. 2004. Physiology of GDF9 and BMP15 signalling molecules. Anim Reprod Sci, 82/83:447-460.

Juengel JL, Reader KL, Bibby AH, Lun S, Ross I, Haydon LJ, McNatty KP. 2006. The role of bone morphogenetic proteins 2, 4, 6 and 7 during ovarian follicular development in sheep: contrast to rat Reproduction, 131:501-513.

Knight PG, Glister C. 2003. Local roles of TGF-beta superfamily members in the control of ovarian follicle development. Anim Reprod Sci, 78:165-183.

Knight PG, Glister C. 2006. TGF-beta superfamily members and ovarian follicle development. Reproduction, 132:191-206.

Land RB, Fordyce M, Gauld IK, Morris BA, Webb R. 1983. Fertility of sheep given antisera to steroids during anoestrus. J Reprod Fertil, 67:269-273.

Leroy JLMR, Sturmey RG, Van Hoeck V, De Bie J, McKeegan PJ, Bols PEJ. 2013. Dietary lipid supplementation on cow reproductive performance and oocyte and embryo viability: areal benefit? Anim Reprod, 10:258-267.

Letelier C, Mallo F, Encinas T, Ros JM, GonzalezBulnes A. 2008. Glucogenic supply increases ovulation rate by modifying follicle recruitment and subsequent development of preovulatory follicles without effects on ghrelin secretion. Reprod Res, 136:65-72.

Lucy MC. 2000. Regulation of ovarian follicular growth by somatotropins and insulin-like growth factors in cattle. J Dairy Sci, 83:1635-1647.

Lucy MC. 2003. Mechanisms linking nutrition and reproduction in postpartum cows. Reproduction Suppl, 61:415-427.

Machado MF, Portela VM, Price CA, Costa IB, Ripamonte P, Amorim RL, Buratini Jr J. 2009. Regulation and action of fibroblast growth factor 17 in bovine follicles. J Endocrinol, 202:347-353.
Macías R, Pinzón C, Fierro F, Vergara M, Martínez D, Rosado A, Gutiérrez CG, Rosales-Torres AM. 2012. Identification of soluble forms of vascular endothelial growth factor receptors, sVEGFR-1 and sVEGFR-2, in bovine dominant follicles. Reprod Domest Anim, 47:39-42.

Martin GB, Price CA, Thiery J-C, Webb R. 1988. Interactions between inhibin, oestradiol and progesterone in the control of gonadotrophin secretion in the ewe. J Reprod Fertil, 82:319-328.

Martin GB. 2009. The 'Clean, Green and Ethical' concept in animal production. Agrociencia, 12:1-7.

Martínez V. 2004. Efecto del tratamiento con una solución glucogénica oral sobre la tasa de ovulación en ovejas Pelibuey. Ciudad de Mexico: Facultad de Medicina Veterinaria y Zootecnia, UNAM. Tesis (Maestría en Ciencias).

McNatty KP, Juengel JL, Wilson T, Galloway SM, Davis GH. 2001. Genetic mutations influencing ovulation rate in sheep. Reprod Fertil Dev, 13:549-555. McNatty KP, Reader K, Smith P, Heath DA, Juengel JL. 2007. Control of ovarian follicular development to the gondatrophin-dependent phase: a 2006 perspective. In: Juengel JL, Murray JF, Smith MF. (Ed.). Reproduction in Domestic Ruminats VI. Cambridge, UK: Nottingham University Press. pp. 55-68.

McNatty KP, Juengel JL, Pitman JL. 2014. Oocytesomatic cell interactions and ovulation rate: effects on oocyte quality and embryo yield. Reprod Biol Insights, 7:1-8. doi:10.4137/RBi.s12146.

Mihm M, Evans AC. 2008. Mechanisms for the dominant follicle selection in monovulatory species: a comparison of morphological, endocrine and intraovarian events in cows, mares and women. Reprod Domest Anim, 43:48-56.

Monniaux D, Barbey S, Rico C, Fabre S, Gallard Y, Larroque H. 2010. Anti-Mullarian hormone: a predictive marker of embryo production in cattle? Reprod Fertil Dev, 22:1083-1091.

Monniaux D, Clément F, Dalbiès-Tran R, Estienne A, Fabre S, Mansanet C, Monget P. 2014. The ovarian reserve of primordial follicles and the dynamic reserve of antral growing follicles: what is the link? Biol Reprod, 90:85. doi: 10.1095/biolreprod.113.117077.

Monteagudo LV, Ponz R, Tejedor MT, Lavina A, Sierra I. 2009. A 17 bp deletion in the bone morphogenetic protein 15 (BMP15) gene is associated to increased prolificacy in the Rasa Aragonesa sheep breed. Anim Reprod Sci, 110:139-146.

Morley FHW, White D H, Kenney PA, Davis IF. 1978. Predicting ovulation rate from liveweight in ewes. Agric Systems, 3:27-45.

Mossa F, Walsh S, Butler ST, Berry DP, Carter F, Lonergan P, Smith GW, Ireland JJ, Evans ACO. 2012. The number of ovarian follicles $\geq 3 \mathrm{~mm}$ in diameter is positively associated with fertility in dairy cows. J Dairy Sci, 95:2355-2361.

Mossa F, Carter F, Walsh SW, Kenny DA, Smith W, Ireland JL, Hildebrandt TB, Lonergan P, Ireland JJ, Evans AC. 2013. Maternal undernutrition in cows impairs ovarian and cardiovascular systems in their offspring. Biol Reprod, 88:92. doi:10.1095/ 
biolreprod.112.107235.

Mottershead DG, Harrison CA, Mueller TD, Stanton PG, Gilchrist RB, McNatty KP. 2013. Growth differentiation factor 9:bone morphogenetic protein 15 (GDF9:BMP15) synergism and protein heterodimerization. Proc Natl Acad Sci USA, 110:E2257. doi: 10.1073/pnas.1303459110.

Mulsant P, Lecerf F, Fabre S, Schibler L, Monget P, Lanneluc I, Pisselet C, Riquet J, Monniaux D, Callebaut I, Cribiu E, Thimonier J, Teyssier J, Bodin L, Cognié Y, Chitour N, Elsen J-M. 2001. Mutation in bone morphogenetic protein receptor-IB is associated with increased ovulation rate in Booroola Merino ewes. Proc Natl Acad Sci USA, 98:5104-5109.

Muñoz-Gutierrez M, Blache D., Martin GB, Scaramuzzi RJ. 2002. Folliculogenesis and ovarian expression of mRNA encoding aromatase in anoestrous sheep after 5 days of glucose or glucosamine infusion or supplementary lupin feeding. Reproduction, 124:721731.

Muñoz-Gutierrez M, Blache D, Martin GB, Scaramuzzi RJ. 2004. Ovarian follicular expression of mRNA encoding the type I IGF receptor and IGFbinding protein-2 in sheep following five days of nutritional supplementation with glucose, glucosamine or lupins. Reproduction, 128:747-756.

Narkwichean A, Jayaprakasan K, Maalouf WE, Hernandez Medrano JH, Pincott-Allen C, Campbell BK. 2014. Effects of dehydroepiandrosterone on in vivo ovine follicular development. Hum Reprod, 29:146-154. Nicholas B, Scougall RK, Armstrong DG, Webb R 2002. Changes in insulin-like growth factor binding protein (IGFBP) isoforms during bovine follicular development. Reproduction, 124:439-446.

Nicholas B, Alberio R, Fouladi-Nashta AA, Webb R. 2005. Relationship between low-molecular-weight insulin-like growth factor-binding proteins, caspase-3 activity, and oocyte quality. Biol Reprod, 72:796-804.

Nicol L, Bishop SC, Pong-Wong R, Bendixen C, Holm LE, Rhind SM, McNeilly AS. 2009. Homozygosity for a single base-pair mutation in the oocyte-specific GDF9 gene results in sterility in Thoka sheep. Reproduction, 138:921-933.

Niswender GD, Reichert LE, Midgley AR, Nalbandov AV. 1969. Radioimmunoassay for bovine and ovine luteinizing hormone. Endocrinology, 84:1166-1173.

Otsuka F, McTavish KJ, Shimasaki S. 2011. Integral role of GDF-9 and BMP-15 in ovarian function. Mol Reprod Dev, 78:9-21.

Peters H, Byskov AG, Himelstein-Braw R, Faber M. 1975. Follicular growth: the basic event in the mouse and human ovary. J Reprod Fertil, 45:559-566.

Pierson RA, Ginther OJ. 1984. Ultrasonography of the bovine ovary. Theriogenology, 21:495-504.

Pieterse MC, Kappen KA, Kruip TA, Taverne MA 1988. Aspiration of bovine oocytes during transvaginal ultrasound scanning of the ovaries. Theriogenology, 30:751-762.

Portela VM, Machado M, Buratini Jr. J, Zamberlam G, Amorim RL, Goncalves P, Price CA. 2010 , Expression and function of fibroblast growth factor 18 in the ovarian follicle in cattle. Biol Reprod, 83:339-
346.

Price CA, Morris BA, O'Shea T, Webb R. 1987. Active immunization of cattle against partly purified follicular fluid from sheep. J Reprod Fertil, 81:161-168.

Price CA, Webb R. 1988. Steroid control of gonadotropin secretion and ovarian function in heifers. Endocrinology, 122:2222-2231.

Price CA, Webb R. 1989. Ovarian response to hCG treatment during the oestrous cycle in heifers. $J$ Reprod Fertil, 86:303-308.

Rajakoski E. 1960. The ovarian follicle system in sexually mature heifers with special reference to seasonal, cyclical and left-right variations. Acta Endocrinol (Copenh), 34(suppl. 52):1-68.

Rey R, Lukas-Croisier C, Lasala $C$, Bedecarrás $\mathbf{P}$. 2003. AMH/MIS: what we know already about the gene, the protein and its regulation. Mol Cell Endocrinol, 211:21-31.

Rico C, Médigue C, Fabre S, Jarrier P, Bontoux M, Clément F, Monniaux D. 2011. Regulation of AntiMüllerian hormone production in the cow: a multiscale study at endocrine, ovarian, follicular, and granulosa cell levels. Biol Reprod, 84:560-571.

Robinson RS, Woad KJ, Hammond AJ, Laird M, Hunter MG, Mann GE. 2009. Angiogenesis and vascular function in the ovary. Reproduction, 138:869881.

Rosales-Torres AM, Alonso I, Vergara M, Romano MC, Castillo-Juárez H, Ávalos A, Rosado A, Gutiérrez CG. 2010. Vascular endothelial growth factor isoforms 120, 164 and 205 are reduced with atresia in ovarian follicles of sheep. Anim Reprod Sci, 122:111-117

Royal MD, Darwash AO, Flint APF, Webb R, Woolliams JA, Lamming GE. 2000. Declining fertility in dairy cattle: changes in traditional and endocrine parameters of fertility. Anim Sci, 70:487-501.

Sartori R, Guardieiro MM, Surjus RS, Melo LF, Prata AB, Ishiguro M, Bastos MR, Nascimento AB. 2013. Metabolic hormones and reproductive function in cattle. Anim Reprod, 10:199-205.

Scaramuzzi RJ, Adams NR, Baird DT, Campbell BK, Downing JA, Findlay JK, Henderson KM, Martin GB, McNatty KP, McNeilly AS, Tsonis CG. 1993. A model for follicle selection and the determination of ovulation rate in the ewe. Reprod Fertil Dev, 5:459-478.

Scaramuzzi R, Martin GB. 2008. The importance of interactions among nutrition, seasonality and sociosexual factors in the development of hormone-free methods for controlling fertility. Reprod Domest Anim, 43(suppl. 2):129-136.

Scaramuzzi RJ, Baird DT, Campbell BK, Driancourt MA, Dupont J, Fortune JE, Gilchrist RB, Martin GB, McNatty KP, McNeilly AS, Monget P, Monniaux D, Viñoles C, Webb R. 2011. Regulation of folliculogenesis and the determination of ovulation rate in ruminants. Reprod Fertil Dev, 23:444-467.

Souza CJH, Campbell BK, Webb R, Baird DT. 1997. Secretion of inhibin A and follicular dynamics throughout the oestrous cycle in sheep with and without the Booroola gene (FecB). Endocrinology, 56:483-488. 
Souza CJH, MacDougall C, Campbell BK, McNeilly AS, Baird DT. 2001. The Booroola (FecB) phenotype is associated with a mutation in the bone morphogenetic receptor type $1 \mathrm{~B}$ (BMPR1B) gene. $J$ Endocrinol, 169:R1-6.

Souza CJH, Campbell BK, McNeilly AS, Baird DT 2002. Effect of bone morphogenetic protein 2 (BMP2) on oestradiol and inhibin A production by sheep granulosa cells, and localization of BMP receptors in the ovary by immunohistochemistry. Reproduction, 123:363-369.

Staigmiller RB, England BG, Webb R, Short RE, Bellows RA. 1982. Estrogen secretion and gonadotropin binding by individual bovine follicles during estrus. $J$ Anim Sci, 55:1473-1482.

Taylor PD, Wilson H, Hillier SG, Wiegand SJ, Fraser HM. 2007. Effects of inhibition of vascular endothelial growth factor at time of selection on follicular angiogenesis, expansion, development and atresia in the marmoset. Mol Hum Reprod. 13:729-736.

Themmen AP. 2005. Anti-Mullerian hormone: its role in follicular growth initiation and survival and as an ovarian reserve marker. J Natl Cancer Inst Monogr, $34: 18-21$.

Turnbull K, Braden A, Mattner P. 1977. The pattern of follicular growth and atresia in the ovine ovary. Aust J Biol Sci, 30:229-241.

van Houten EL, Themmen AP, Visser JA. 2010. AntiMullerian hormone (AMH): regulator and marker of ovarian function. Ann Endocrinol (Paris), 71:191-197.

Viñoles C, Forsberg M, Martin G, Cajarville C, Repetto J, Meikle A. 2005. Short-term nutritional supplementation of ewes in low body condition affects follicle development due to an increase in glucose and metabolic hormones. Reprod Res, 129:299-309.

Walsh SW, Mossa F, Butler ST, Berry DP, Scheetz D, Jimenez-Krassel F, Tempelman RJ, Carter F, Lonergan P, Evans AC, Ireland JJ. 2014. Heritability and impact of environmental effects during pregnancy on antral follicle count in cattle. J Dairy Sci, 97:45034511.

Wang TT, Ke ZH, Song Y, Chen LT, Chen XJ, Feng C, Zhnag D, Wu YT, Zhang Y, Sheng JZ, Huang HF. 2013. Identification of a mutation in GDF9 as a novel cause of diminished ovarian reserve in young women. Hum Reprod, 28:2473-2481.

Webb R, England BG. 1982a. Identification of the ovulatory follicle in the ewe: associated changes in follicular size, thecal and granulosa cell luteinising hormone receptors, antral fluid steroids and circulating hormones during the preovulatory period. Endocrinology, 110:873-881.

Webb R, England BG. 1982b. Relationship between LH receptor concentrations in thecal and granulosa cells and in-vivo and in-vitro steroid secretion by ovine follicles during the pre-ovulatory period. $J$ Reprod Fertil, 66:169-180.

Webb R, Baxter G, McBride D, Nordblom GD, Shaw MPK. 1985 The measurement of testosterone and oestradiol-17ß using iodinated tracers and incorporating an affinity chromatography extraction procedure. $J$ Steroid Biochem, 23:1043-1051.

Webb R. 1987. Increasing ovulation rate and lambing rate in sheep by treatment with a steroid enzyme inhibitor. J Reprod Fertil, 79:231-240.

Webb R, Gauld IK, Driancourt MA. 1989. Morphological and functional characterization of large antral follicles in three breeds of sheep with different ovulation rates. $J$ Reprod Fertil, 87:243-255.

Webb R, Gong JG, Law AS, Rusbridge SM. 1992. Control of ovarian function in cattle. $J$ Reprod Fertil Suppl, 45:141-156.

Webb R, Gong JG, Bramley TA. 1994. Role of growth hormone and intrafollicular peptides in follicle development in cattle. Theriogenology, 41:25-30.

Webb R, Campbell BK, Garverick HA, Gong JG, Gutierrez CG, Armstrong DG. 1999. Molecular mechanisms regulating follicular recruitment and selection. J Reprod Fertil Suppl, 54:33-48.

Webb R, Nicholas B, Gong JG, Campbell BK, Gutierrez CG, Garverick HA, Armstrong DG. 2003. Mechanisms regulating follicular development and selection of the dominant follicle. Reproduction Suppl, 61:71-90.

Webb R, Campbell BK. 2007. Development of the dominant follicle: mechanisms of selection and maintenance of oocyte quality. Soc Reprod Fertil Suppl, 64:141-163.

Webb R, Garnsworthy PC, Campbell BK, Hunter MG. 2007: Intra-ovarian regulation of follicular development and oocyte competence in farm animals. Theriogenology, 68(suppl. 1):S22-S29.

Wilson T, Wu X-Y, Juengel JL, Ross IK, Lumsden JM, Lord EA, Dodds KG, Walling GA, McEwan JC, O'Connell AR, McNatty KP, Montgomery GW. 2001. Highly prolific Booroola sheep have a mutation in the intracellular kinase domain of bone morphogenetic protein IB receptor (ALK-6) that is expressed in both oocytes and granulosa cells. Biol. Reprod, 64:12251235.

Wiltbank MC, Sartori R, Herlihy MM, Vasconcelos JL, Nascimento AB, Souza AH, Ayres H, Cunha AP, Keskin A, Guenther JN, Gumen A. 2011. Managing the dominant follicle in lactating dairy cows. Theriogenology, 76:1568-1582.

Wright LA, Rhind SM, Russel AJF, Whyte TK McBean AJ. 1987. The effect of body condition, food level and temporary calf separation on the postpartum anoestrous period and LH and FSH levels in beef cows. Anim Prod, 44:467-468. 